\title{
FREKUENSI PEMUNCULAN, TINGKAH LAKU, DAN DISTRIBUSI MAMALIA LAUT DI LAUT SAWU, NUSA TENGGARA TIMUR
}

\author{
Dharmadi'), Ria Faizah"1), dan Ngurah Nyoman Wiadnyana ${ }^{2)}$ \\ 1) Peneliti pada Pusat Penelitian Pengelolaan Perikanan dan Konservasi Sumber Daya Ikan, Ancol-Jakarta \\ 2) Peneliti pada Balai Riset Perikanan Perairan Umum, Mariana-Palembang \\ Teregistrasi I tanggal: 9 Maret 2010; Diterima setelah perbaikan tanggal: 5 Nopember 2010; \\ Disetujui terbit tanggal: 16 Nopember 2010
}

\begin{abstract}
ABSTRAK
Penelitian mamalia laut dilakukan pada bulan Juli dan Desember tahun 2005 di perairan Laut Sawu, Nusa Tenggara Timur. Tujuan penelitian ini untuk mengetahui tingkah laku, frekuensi pemunculan, dan pola penyebaran mamalia laut. Metode survei menggunakan garis transek dengan pola zig-zag dan dilengkapi dua pengamat (double observer). Delapan spesies mamalia laut yang terdiri atas paus dan lumba-lumba berhasil diidentifikasi, yaitu ikan paus sperma (Physeter macrocephalus), paus pilot (Globicephala macrorhynchus), paus pembunuh kerdil (Feresa attenuata), paus pembunuh (Pseudorca crasidens), lumba-lumba paruh panjang (Stenella longirostris), lumbalumba botol (Stenella attenuata), lumba-lumba fraser (Lagenodelphis hosei), dan lumba-lumba hidung botol (Tursiop truncatus). Tingkah laku mamalia laut yang teridentifikasi selama pengamatan adalah berburu mangsa, melompat ke atas permukaan air, dan berenang menuju arah tertentu. Frekuensi pemunculan tertinggi dilakukan oleh Stenella longirostris yaitu 245 kali atau 84,1\% kehadiran pada bulan Juli dan 994 kali atau 60,8\% kehadiran pada bulan Desember 2005. Distribusi mamalia laut di Laut Sawu sebagian besar terkonsentrasi di sekitar perairan Lembata, Pantar, dan Alor, Nusa Tenggara Timur yang juga didominansi oleh Stenella longirostris.
\end{abstract}

KATAKUNCI: $\quad$ frekuensi pemunculan, tingkah laku, distribusi, mamalia laut, Laut Sawu-Nusa Tenggara Timur

ABSTRACT: $\quad$ Sighting frequency, behavior, and distribution of cetacean in the Sawu Sea East Nusa Tenggara. By: Dharmadi, Ria Faizah, and Ngurah Nyoman Wiadnyana

Study on mamals was conducted in the Sawu Sea, East Nusa Tenggara on July and December 2005. The objectives of these research are to study the sighting frequency and the distribution patterns of marine mammals. Survey was conducted using line transect with zig-zag patern that equiped by two observer. Eight species of cetacean, namely sperm whale (Physeter macrocephalus), short fin pilot whale (Globicephala macrorhynchus), false killer whale (Pseudorca crasidens), pigmy killer whale (Feresa attenuata), spinner dolphin (Stenella longirostris), spotted dolphin (Stenella attenuata), fraser's dolphin (Lagenodelphis hosei), and bottlenose dolphin (Tursiops truncatus). The cetacean behavior during observation are hunting, forfeed jumping in the air, and travelling to certain direction. Stenella longirostris is the frequent observed species compared to the others, where 245 sightings (84,1\%) on July and 994 sightings (60,8\%) on December 2005. The cetacean distributed in the Lembata, Pantar, and Alor waters, East Nusa Tenggara was dominated by spinner dolphin (Stenella longirostris).

KEYWORDS: $\quad$ sighting frequency, behavior, distribution, cetacean, Sawu Sea-East Nusa Tenggata

\section{PENDAHULUAN}

Perairan Indonesia dikenal memiliki keanekaragaman biota yang tinggi di dunia termasuk keanekaragaman mamalia laut yang tinggi di dunia. Menurut (Barnes, 1996; Rudolp et. al. 1997; Kahn, 2003) terdapat sekitar 30 jenis paus dan lumba-lumba di perairan Indonesia dari total 86 jenis yang ada di dunia. Setengah dari seluruh jenis mamalia laut Indonesia dapat ditemukan di Laut Sawu terutama sebelah selatan Lembata (Lamalera). Kelompok mamalia laut tergolong hewan berumur panjang dan pertumbuhannya lambat, sehingga menyebabkan sangat rentan terhadap tekanan penangkapan yang berlebihan. Pada tahun 1957-1979 terjadi penangkapan beberapa jenis mamalia laut yaitu jenis Physeter catodon 373 ekor, Orcinus orca lebih dari lima ekor, Globicephala macrorhynchus lebih dari 33 ekor, dan lumba-lumba lebih dari 109 ekor. Tahun 1959-1994 di perairan Lamalera tertangkap 612 ekor paus sperma (Barnes, 1996). Sedangkan tahun 19741975 paus yang tertangkap kapal FAO adalah Physeter catodon 29 ekor terdiri atas 11 jantan dan 18 betina, beberapa di antaranya matang kelamin 
berukuran panjang 7,20 dan 16,50 m. Globicephala macrorhynchus satu ekor betina matang kelamin berukuran panjang 9,50 m (Silalahi \& Suwelo, 2003).

Menurut Cawardine (1995) identifikasi mamalia laut dapat dilakukan dengan cara melihat beberapa tanda atau ciri-ciri yang ada, antara lain ukuran tubuh, ada tidaknya sirip dorsal (jika ada, dilihat bentuk, ukuran, dan posisi terhadap badan), warna dan tandatanda, serta pola ditubuhnya, karakteristik semburan air dari lubang hidung, (bentuk tubuh, kepala, dan moncongnya), bentuk ekor, dan tanda-tandanya, tingkah laku di permukaan dan buruan waktu menyelam, breaching, dan aktivitas lain, jumlah hewan yang diamati, dan penambilan gambar atau foto untuk identifikasi lebih lanjut.

Tujuan penelitian ini adalah untuk mengetahui frekuensi pemunculan dan pola penyebaran mamalia laut di Laut Sawu, Nusa Tenggara Timur.

\section{BAHAN DAN METODE}

Penelitian ini dilakukan di perairan Pantar, Lamalera, dan Lembata pada bulan Juli 2005 dan di perairan Alor bagian selatan, Pantar bagian selatan, dan Selat Pantar, Nusa Tenggara Timur pada bulan Desember 2005. Alat bantu yang digunakan adalah Kamera SLR EOS 10D (80 mm); Binokuler zenith 7x50; Nikon 12x50, Laptop, GPS garmin, peta bathymetri Laut Sawu, dan sekitarnya serta buku Identifikasi menggunakan acuan Cawardine (2002).
Sarana penelitian yang digunakan adalah kapal layar motor.

Metode survei menggunakan line transect pola zigzag dengan dua kelompok pengamat (WWFHongkong, 2003). Metode line transect zig-zag bertujuan untuk menghindari cahaya yang menyilaukan (glare) yang ditimbulkan oleh adanya sinar matahari. Pembagian kelompok pengamatan survei disajikan pada Gambar 1 dengan keterangan sebagai berikut:

1. Seorang pengamat yang disebut big eye menempati posisi di dek bagian atas.

2. Big eye bertugas untuk melihat ke arah cakrawala sejauh 10 kiri dan kanan dari arah haluan dengan binokuler $12 \times 50 \mathrm{~mm}$.

3. Dua orang pengamat sebelah kiri dan kanan (pengamat utama) yang berada di dek depan haluan kapal bertugas melihat $500 \mathrm{~m}$ dengan sudut pandang $0-90^{\circ}$ dari haluan kapal dengan mata telanjang atau dibantu binokuler berukuran $7 \times 50$ $\mathrm{mm}$.

4. Seorang notulen mendampingi big eye mencatat pengamatan big eye dan pengamat kiri dan kanan serta kondisi cuaca (skala beaufort), posisi geografis, dan kegiatan perikanan di sekitarnya. Big eye tidak melakukan percakapan dengan pengamat kiri dan kanan untuk menjamon independensi pengamatan, tetapi kedua pengamat ini dapat berkomunikasi dengan big eye dan notulen (Gambar 1). Sering kali pengamatan mengkonfirmasi pengamatan yang dilakukan big eye sebelumnya.

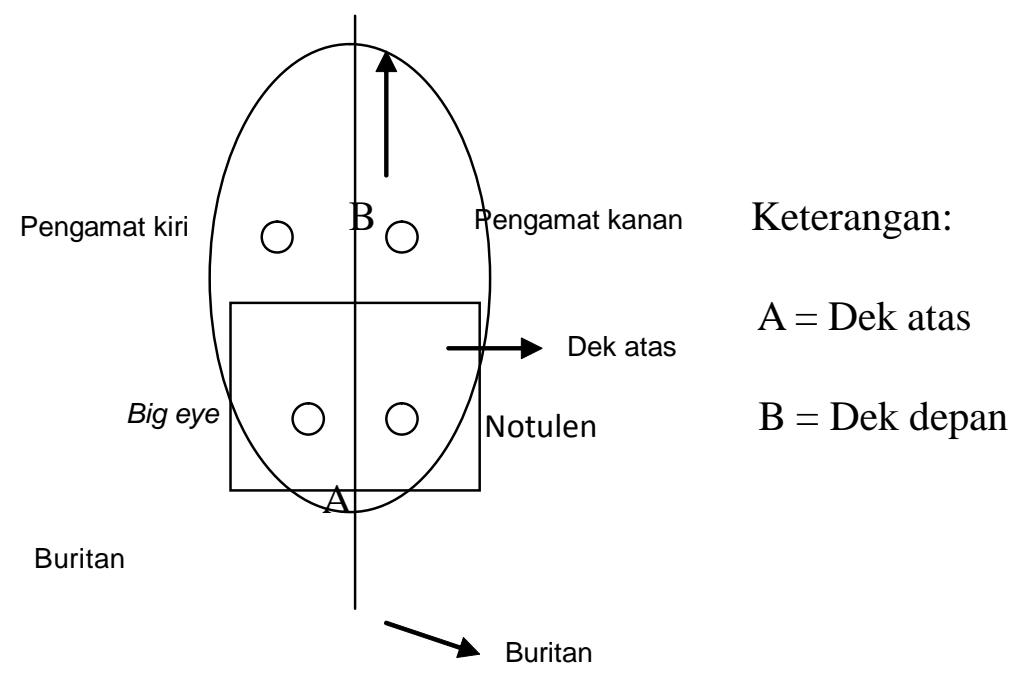

Gambar 1. Posisi para pengamat di KLM. Rima

Figure 1. The position of observers in the deek of R.V. Rima. 
Tiap posisi ditempati selama satu jam, kemudian posisi dirotasi. Pada saat seorang peneliti menyelesaikan posisi big eye, peneliti tersebut beristirahat selama satu jam. Setiap pengamatan yang dilakukan sepanjang garis transek disebut pengamatan on effort (Porter \& Chilver, 2002). Pengamatan lain yang off effort dilakukan di luar garis transek, atau jika kondisi cuaca sangat buruk. Pengamatan on effort dapat dibagi menjadi dua yaitu closing mode dan passing mode. Closing mode yaitu jika kapal mengubah haluan saat sasaran teramati oleh pengamat guna mengambil gambar yang lebih rinci. Pengamat memperkirakan jarak dan sudut terhadap haluan kapal dan menghitung jumlah kelompok dan pengamatan tingkah laku. Dalam satu hari dilakukan pengamatan $3 \times 30$ menit. Jika ada sasaran lain yang teramati selama kapal kembali ke jalur awal, pengamatan tersebut dimasukan dalam pengamatan sekunder. Passing Mode yaitu jika kapal melewati kelompok sasaran saat pengamatan. Waktu pengamatan, perkiraan jarak, sudut terhadap haluan, posisi geografis, dan kondisi cuaca juga dicatat seperti halnya closing mode.
Untuk menghindari silau matahari saat kapal menghadap ke arah matahari, karena haluan kapal diubah arahnya $20^{\circ}$ menjauhi garis transek ke arah berlawanan dari matahari. Garis transek baru ini kemudian diperlakukan sebagai garis transek sejati sepanjang 6 mil laut. Setelah silau teratasi, kapal secepatnya kembali ke garis haluan semula, namun jika silau mengganggu, sebaiknya kapal tetap pada garis transek baru sejauh 6 mil laut (berlawanan dengan arah transek awal) dan membuat pola zigzag yang baru sampai silau teratasi.

Untuk mengetahui koordinat sesungguhnya dari sasaran, maka dilakukan konversi dari derajat lintang dan bujur kapal dengan sudut sasaran terhadap haluan dan perkiraan jarak langsung dari pengamat ke sasaran. Dengan mengetahui jarak tegak lurus dari kapal ke sasaran maka diperoleh perkiraan di mana sasaran pertama dilihat. Perhitungan detil jarak tegak lurus dapat dilihat pada Gambar 2, sedangkan peta pelayaran pengamatan cetacean pada bulan Juli dan Desember 2005 disajikan dalam Gambar 3.

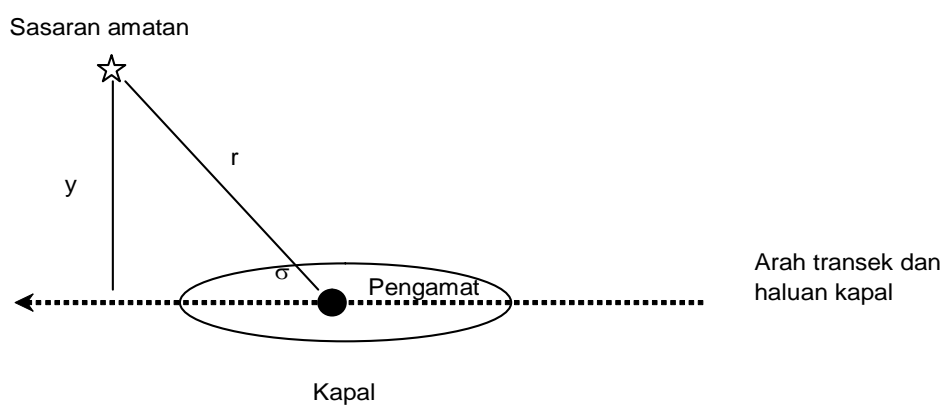

Gambar 2. Perhitungan jarak tegak lurus (perpendicular distance) pengamatan.

Figure 2. The calculation of the perpendicular distance (perpendicular distance) observations. Keterangan/Remarks: $\mathrm{R}=$ perkiraan jarak dari pengamat ke sasaran; $\sigma=$ perkiraan sudut antara haluan kapal dengan sasaran; jarak tegak lurus $=y=r \sin \sigma$

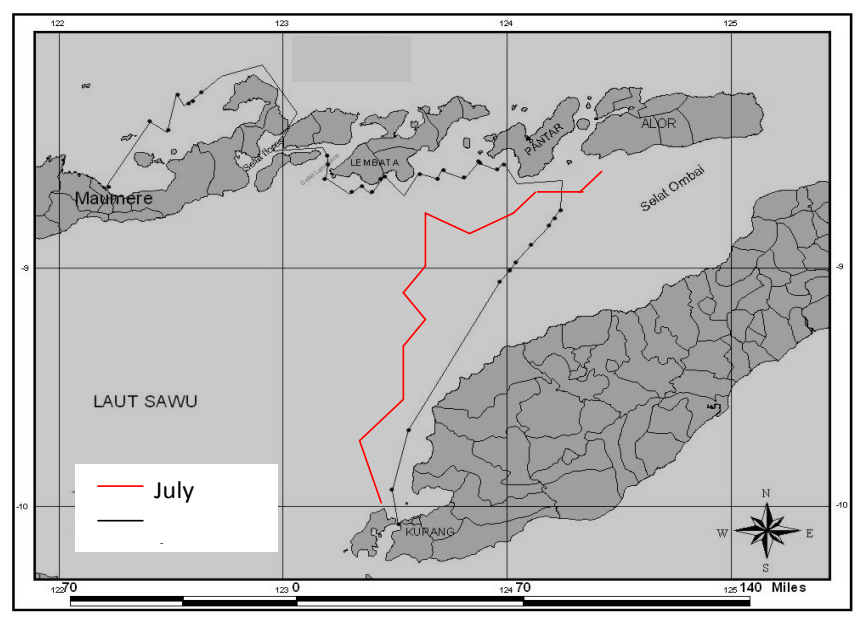

Gambar 3.

Peta pelayaran pengamatan cetacean, bulan Juli dan December 2005.

Figure 3. Cruise track of cetacean observation, July and December 2005. 


\section{HASIL DAN BAHASAN}

\section{Tingkah Laku dan Frekuensi Pemunculan Mamalia Laut}

Hasil pengamatan mamalia laut berdasarkan atas

Tabel 1.

Table 1. identifikasi jenis dan frekuensi pemunculannya pada periode bulan Juli dan Desember 2005 disajikan pada Tabel 1 dan 2.

\begin{tabular}{|c|c|c|c|c|c|c|}
\hline \multirow[t]{2}{*}{ Jenis/Type } & \multicolumn{4}{|c|}{$\begin{array}{c}\text { Pengamatan hari ke/ } \\
\text { Observation day }\end{array}$} & \multirow[t]{2}{*}{ Total } & \multirow{2}{*}{$\begin{array}{c}\text { Kehadiran/ } \\
\text { Attendance } \\
(\%)\end{array}$} \\
\hline & 1 & 2 & 3 & 4 & & \\
\hline \multicolumn{7}{|l|}{ Lumba-lumba: } \\
\hline - Stenella longirostris & 84 & 65 & 53 & 43 & 245 & 84,1 \\
\hline - Stenella attenuata & 4 & 7 & 6 & 5 & 22 & 7,6 \\
\hline - Un-identified & 12 & 10 & - & - & 22 & 7,6 \\
\hline \multicolumn{7}{|l|}{ Paus: } \\
\hline - Baleen & 2 & - & - & - & 2 & 0,7 \\
\hline Total & 102 & 82 & 59 & 48 & 291 & 100 \\
\hline
\end{tabular}

Tabel 2.

\begin{tabular}{|c|c|c|c|c|c|c|}
\hline \multirow[t]{2}{*}{ Jenis/ Type } & \multicolumn{4}{|c|}{$\begin{array}{l}\text { Pengamatan hari ke/ } \\
\text { Observation day }\end{array}$} & \multirow[t]{2}{*}{ Total } & \multirow[t]{2}{*}{$\begin{array}{c}\text { Kehadiran/ } \\
\text { Attendance } \\
(\%)\end{array}$} \\
\hline & 1 & 2 & 3 & 4 & & \\
\hline \multicolumn{7}{|l|}{ Lumba-lumba: } \\
\hline - Stenella longirostris & 182 & 548 & 157 & 107 & 994 & 60,8 \\
\hline - Stenella attenuata & & 21 & & - & 21 & 1,3 \\
\hline - Lagenodelphis hosei & - & 40 & - & - & 40 & 2,4 \\
\hline - Tursiops truncates & - & 36 & - & - & 36 & 2,2 \\
\hline - Feresa attenuate & - & - & 40 & 64 & 104 & 6,4 \\
\hline - Un-identified & - & 110 & 27 & 24 & 161 & 9,8 \\
\hline \multicolumn{7}{|l|}{ Paus: } \\
\hline - Globicephala macrorhynchus & - & 67 & 149 & 35 & 251 & 15,3 \\
\hline - Pseudorca crasidens & - & 13 & & 4 & 17 & 1,0 \\
\hline - Physeter macrocephalus & - & 11 & - & 3 & 12 & 0,7 \\
\hline Total & 182 & 476 & 155 & 255 & 1.636 & 100 \\
\hline
\end{tabular}

Hasil pengamatan pemunculan mamalia laut pada bulan Juli tercatat hanya tiga spesies yang teridentifikasi dua spesies lumba-lumba yaitu lumbalumba paruh panjang, dan lumba-lumba botol, dan satu spesies paus yaitu paus baleen. Sedangkan frekuensi pemunculan Stenella longirostris 245 kali dengan persentase kehadiran $84,1 \%$, jenis Stenella attenuate 22 kali dengan persentase kehadiran hanya $1,9 \%$. Spesies mamalia laut yang tidak teridentifikasi diperkirakan jenis yaitu paus baleen dua kali pemunculan dan lumba-lumba 22 kali pemunculan. Tingkah laku lumba-lumba selama pengamatan dapat dikategorikan sebagai lumba-lumba berburu mangsa, melompat ke atas permukaan air dan berenang, sedangkan tingkah laku paus terlihat pada saat akan menyelam. Tingkah laku lumba-lumba yang sedang berburu mangsa terutama terjadi saat pengamatan pada pagi sampai siang hari. Menurut Shane (1990); Purnomo (2001) pemunculan lumba-lumba diduga berkaitan dengan kebiasaan makan sebagai aktivitas harian yang pada umumnya dilakukan pada pagi sampai sore hari. Menurut Setiawan (2004) tingkah laku lumba-lumba yang sering terlihat dengan cara melompat ke atas permukaan air (aerials), merupakan salah satu cara untuk melakukan komunikasi di antaranya supaya tidak tersesat atau untuk menarik perhatian kelompoknya jika di antaranya ada yang terpisah. Hasil pengamatan bulan Juli hanya teridentifikasi dua jenis dan didominansi oleh lumbalumba paruh panjang. 
Pengamatan bulan Desember 2005 pada hari pertama teridentifikasi satu jenis lumba-lumba yaitu Stenella longirostris dengan frekuensi pemunculan 182 kali yang dijumpai di sekitar perairan Kupang. Tingkah laku lumba-lumba selama pengamatan adalah aerial (melompat ke atas permukaan air) dan travelling (berenang menuju arah tertentu). Pengamatan hari kedua mendapatkan 42 sighting dengan tujuh spesies yang dapat di identifikasi yaitu Stenella longirostris 548 kali pemunculan, Stenella attenuata 21 kali pemunculan, Globicephala macrorhyncus 102 kali pemunculan, Fraser's dolphin 40 kali pemunculan, false killer whale 17 kali pemunculan, bottlenose do/phin 36 kali pemunculan, dan physeter macrocephalus 12 kali pemunculan. Untuk spesies yang tidak teridentifikasi 110 kali pemunculan. Tingkah laku lumba-lumba dan paus saat pengamatan yaitu travelling (berenang menuju arah tertentu), logging (berenang ditempat sambil memunculkan kepalanya ke permukaan berulangulang), dan hunting (berburu). Sedangkan paus dapat diketahui keberadaannya di Laut Sawu ketika sedang menyemburkan air ke atas permukaan, namun tidak diketahui jenisnya. Untuk mengetahui jenis mamalia laut khususnya paus dapat dikenali dengan mengetahui tipe semburannya. Misalnya untuk spesies Physeter macrocephalus famili Physeteridae memiliki tipe semburan relatif rendah mengarah ke depan dan ke kiri, tinggi semburannya dapat mencapai 2-5 m (Cawardine, 2002). Pengamatan hari ketiga mendapatkan 18 sighting dengan tiga spesies teridentifikasi yaitu spinner dolphin (Stenella longirostris) 157 kali pemunculan, feresa attenuate 40 kali pemunculan, dan globicephala macrorhyncus 149 kali pemunculan. Sementara itu lumba-lumba yang tidak teridentifikasi 27 kali pemunculan. Pengamatan hari keempat dengan 23 sighting dijumpai tiga spesies yang teridentifikasi yaitu spinner dolphin 107 kali pemunculan, feresa attenuate 64 kali pemunculan, dan physeter macrocephalus tiga kali pemunculan, salah satunya adalah calf (anak). Lumba-lumba yang tidak teridentifikasi 24 kali pemunculan.

Hasil pengamatan selama empat hari diperoleh delapan jenis mamalia laut yang dapat di identifikasi yaitu Stenella longirostris 994 kali pemunculan, Stenella attenuata 21 kali pemunculan dengan persentase kehadiran Physeter macrocephalus 15 kali pemunculan, feresa attenuate 104 kali pemunculan, Globicephala macrorhyncus 251 kali pemunculan, Pseudorca crassidens 17 kali pemunculan, Lagenodelphis hosei 40 kali pemunculan, Tursiops truncates 36 kali pemunculan, dan 161 kali pemunculan lumba-lumba yang tidak dapat di identifikasi. Jumlah mamalia laut yang di temukan pada bulan Desember 2005 adalah 1.636 kali pemunculan. Mamalia laut yang teramati selama dua trip (bulan Juli dan Desember 2005) adalah 1.927 kali pemunculan. Hasil pengamatan mamalia laut selama penelitian di perairan Lembata, Pantar, dan Alor didominansi oleh lumba-lumba paruh panjang. Mamalia laut melakukan berbagai macam tingkah laku yang berkaitan dengan aktivitas kehidupannya, seperti hunting (berburu mangsa), traveling (berenang menuju arah tertentu), aerial (melompat ke atas permukaan air), dan lain-lain.

Frekuensi pemunculan mamalia laut di Laut Sawu didominansi oleh Stenella longirostris dengan persentase kehadiran pada bulan Juli dan Desember masing-masing 84,1 dan 60,8\%. Perbedaan jumlah individu dan persentase kehadiran dari spesies lumbalumba dan paus yang ditemukan pada periode bulan Juli dan Desember diduga disebabkan oleh faktor kondisi lingkungan perairan yang berbeda dan kelimpahan ketersediaan ikan-ikan pelagis sebagai mangsanya. Pengamatan langsung di lapangan menunjukan bahwa sebagian besar kelompok lumbalumba yang teramati nampak berenang secara bergerombol pada daerah perairan tertentu yang diduga sedang mengejar mangsa. Nowak (1997) mengatakan bahwa spesies paus dan lumba-lumba yang umum ditemukan di perairan daerah tropis di sebelah utara khatulistiwa dan di sebelah selatan Kepulauan Galapagos mampunyai variasi musiman terutama pada saat suhu permukaan perairan relatif kecil. Dari hasil pengamatan lumba-lumba sering kali melakukan aktivitas melompat ke udara dengan terlebih dahulu kepala muncul ke permukaan kemudian menjatuhkan diri kembali ke air. Aktivitas ini dinamakan dengan istilah breaching. Menurut Carwadine (1995) aktivitas ini bertujuan untuk menghilangkan parasit yang menempel dalam tubuh, sebagai pertanda memperlihatkan kekuatan atau hanya sekedar kesenangan atau merupakan suatu bentuk komunikasi pada kelompoknya (Carwadine et al., 1997). Evans (1987) mengatakan bahwa mamalia laut sub ordo Odontoceti cenderung untuk membentuk suatu kelompok yang hidup bersama. Lumba-lumba pelagis seperti genus Stella, Delphinus, dan Lagenorhynchus sering membentuk kelompok besar yang terdiri atas lima sampai ratusan individu. Keuntungan hidup berkelompok akan mempermudah pencarian makanan, proses perkawinan, proses membesarkan anak, serta melindungi diri dari ancaman pemangsa.

\section{Distribusi Mamalia Laut}

Distribusi mamalia laut pada bulan Juli dan Desember 2005 disajikan pada Gambar 4. Spesies 
mamalia laut yang teridentifikasi pada periode tersebut sebagian besar ditemukan di perairan Pantar dan Alor. Perairan Pantar dan Alor dan sekitarnya diduga sebagai tempat berkumpulnya atau sebagai jalur migrasi mamalia laut dari Samudera Hindia ke Laut Banda atau sebaliknya (Perlindungan Hutan dan Pelestarian Alam, 1984). Menurut Leatherwood \& Reeves (1990) distribusi lumba-lumba dapat berpindah dari satu daerah ke daerah lain secara musiman. Menurut Cawardine et al. (1997) ada tiga faktor yang mempengaruhinya yaitu perubahan distribusi musiman dari mangsa, adanya tekanan predator, dan kebutuhan reproduksi.

Aktivitas paus dan lumba-lumba yang muncul ke permukaan tidak tergantung pada kondisi cuaca. Pada saat cuaca berawan, mendung, atau hujan mamalia laut tetap menampakkan diri. Hal ini berkaitan dengan aktivitasnya karena mencari makan, berenang menuju ke arah tertentu mengejar mangsa, atau berenangrenang ditempat sambil menenggelamkan badannya berulang-ulang. Menurut Weber \& Thurman (1991) mamalia laut dapat berada di bawah air pada kedalaman yang cukup untuk waktu yang lama. Kebanyakan berada pada kedalaman 50 m dari kolom air di mana makanan terkonsentrasi pada level kedalaman tersebut, jarang menyelam pada perairan yang lebih dalam. Lumba-lumba mampu mengejar mangsa pada kedalaman sekitar $330 \mathrm{~m}$ dan paus baleen dapat menyelam pada kedalaman lebih dari $350 \mathrm{~m}$.

Purnomo (2001) mengatakan bahwa lumba-lumba seringkali bergerak di permukaan perairan seperti berbaris horisontal atau berkelompok rapat-rapat, selain itu juga terkadang berdiam diri di permukaan sambil memasukan kepalanya ke dalam air berulang kali seperti mengangguk-angguk. Tingkah laku tersebut merupakan salah satu cara lumba-lumba untuk mencari makanannya. Cawardine (1995) mengatakan bahwa lumba-lumba paruh panjang merupakan spesies yang sangat aktif, sehingga kelompok spesies ini jika dilihat dari jarak jauh nampak seperti buih-buih yang disebabkan oleh lompatannya. Lumba-lumba juga perenang yang cepat dan aktif dengan lompatan rendah dan sering, kadang-kadang melempar tubuhnya tinggi-tinggi ke udara, dan sesaat terlihat berada di udara sebelum jatuh ke air.

Menurut Weber \& Thurman (1991) kekuatan berenang mamalia laut berasal dari ekor yang berbentuk seperti sauh, tidak seperti ikan dan hiu yang ekornya vertikal melainkan horisontal. Jenis mamalia laut dominan yang terdapat di perairan Pantar, Alor dari hasil penelitian ini adalah Stenella longirostris. Penyebaran lumba-lumba paruh panjang sangat luas mulai dari daerah laut tropis seperti Samudera Hindia, Samudera Atlantik, Laut Karibia, dan Samudera Pasifik. Lumba-lumba hidup pada suhu antara $24-30^{\circ} \mathrm{C}$ dan Samudera, tapi kadang-kadang hidup di daerah pantai (Phillips, 1998). Sementara itu umba-lumba paruh panjang sering berasosiasi dengan spesies lain seperti Stenella clymene, Stenella attenuata, Delphinus delphis, dan beberapa jenis paus berukuran kecil, tuna sirip kuning, burung laut, dan kemungkinan juga udang-udangan dari berbagai ukuran (Cawardine, 2002).

Lumba-lumba hidung botol kemungkinan dapat ditemukan dalam satu kelompok dengan berbagai jenis mamalia laut, kelompok hiu, dan penyu. Lumbalumba botol merupakan hewan yang sangat aktif dan sering berasosiasi dengan lumba paruh panjang, tuna sirip kuning, dan burung laut. Spesies ini sering terlihat menghindari kapal penangkap ikan atau kapal lain yang sedang melintasi laut. Spesies ini tersebar luas di perairan tropis dan sub tropis. Stenella attenuate dijumpai pada perairan yang bersuhu $>25^{\circ} \mathrm{C}$. Pada umumnya sering ditemukan di perairan sekitar pulaupulau.

Lumba-lumba fraser (Lagenodelphis hosei) merupakan jenis hewan perenang cepat dan agresif. Di perairan sering berasosiasi dengan mamalia laut terutama melon headed, false killer, sperm whales, pantoprical spotted, dan stripped dolphin. Jenis physeter macrocephalus (lodan besar) ditemukan di laut lepas juga di dekat pantai pada kedalaman >200 $\mathrm{m}$. Jalur migrasi sperm whale adalah perairan Samudera Hindia dan Samudera Pasifik (Rice, 1989). Distribusi feresa attenuata kemungkinan tersebar luas di perairan Samudera Hindia sebagai tempat migrasinya. Habitatnya di perairan dalam dan hangat, jarang dijumpai di dekat pulau di wilayah oseanik terutama di daerah tropis. Globicephala macrorhynchus distribusinya sangat luas dan lebih menyukai perairan dalam. Pseudorca crasidens (paus pembunuh palsu) distribusinya sangat luas terutama di laut dalam di Samudera Hindia (Leatherwood \& Donovan, 1991). Kadang-kadang berasosiasi dengan bottlenose dolphins dan jenis udang-udangan berukuran kecil. 

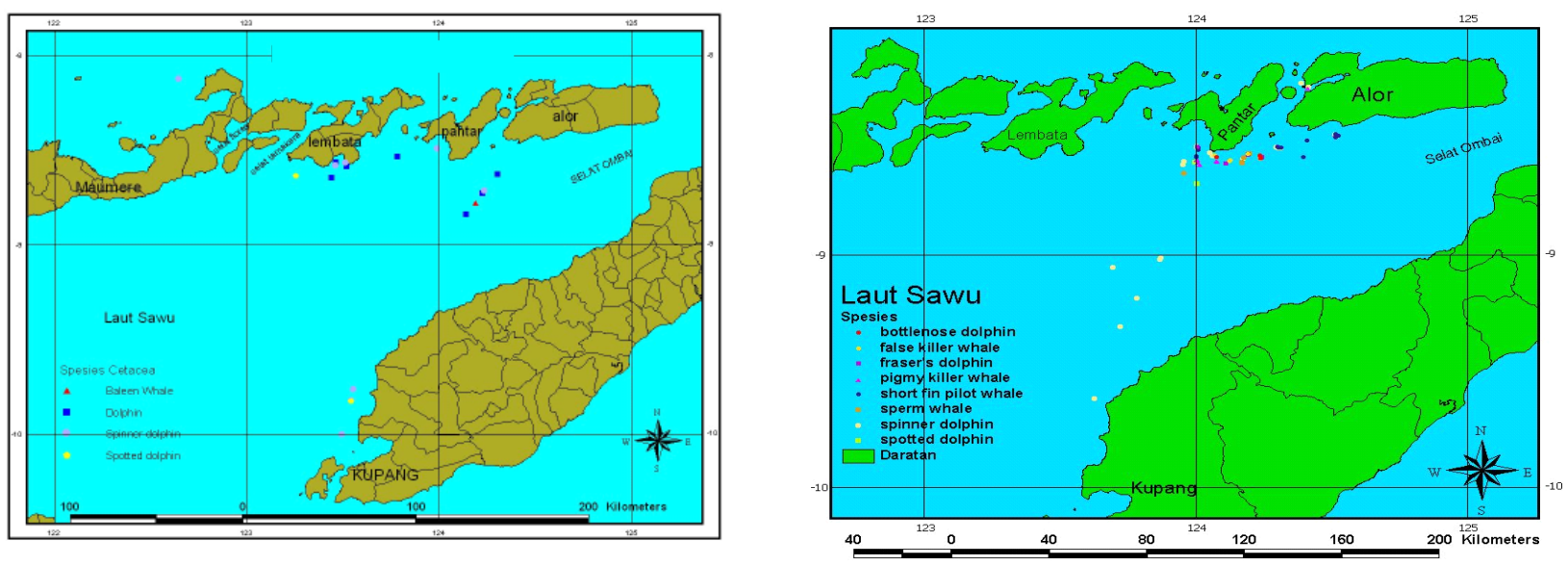

Gambar 4. Distribusi mamalia Laut Sawu selama pengamatan bulan Juli (a) dan Desember (b) 2005. Figure 4. Cetacean distribution in the Sawu sea during observation on July (a) and December (b) 2005.

\section{KESIMPULAN}

1. Selama penelitian di Laut Sawu pada bulan Juli dan Desember 2005, paling tidak terdapat delapan spesies yang terdiri atas ikan paus dan lumbalumba. Lumba-lumba parung panjang merupakan spesies dominan.

2. Berbagai tingkah laku mamalia laut yang nampak diperlihatkan oleh lumba-lumba adalah tingkah laku hunting (berburu mangsa).

3. Distribusi mamalia laut sebagian besar terdapat di perairan Pantar dan Alor. Diduga di sekitar perairan tersebut merupakan daerah agregasi dan jalur migrasi mamalia laut.

\section{PERSANTUNAN}

Tulisan ini merupakan kontribusi dari kegiatan hasil riset inventarisasi mamalia laut, T. A. 2004-2005, di Pusat Riset Perikanan Tangkap-Ancol, Jakarta. Penulis menyampaikan ucapan terima kasih kepada Februyanti Poernomo, Putuliza Kusuma Mustika, Adityo Setiawan, Fajar Ansori, Alvon Hendrian, Ayu Destari, dan Febrina Syahria yang telah membantu selama kegiatan penelitian berlangsung.

\section{DAFTAR PUSTAKA}

Barnes, R. H. 1996. Sea Hunters of Indonesia: Fishers and Weavers of Lamalera. New York. Oxford University Press.

Cawardine, M. 1995. Eye Witness Handbook: Whales, Dolphins and Porpoises. The Visual Guide to All
World's Cetacean. Dorling Kindersley Ltd. New York, N. Y.

Cawardine, M., E. Hoyt, R. E. Fordyce, \& P. Gill. 1997. An Australian Geographic Giude to Whales, Dolphin, and Porpoises. Australian Geographic Press. Australia.

Carwardine, M. 2002. Whales Dolphins and Porpoises. Smithsonian Handbooks. Dorling Kindersley Publishing. Inc. London. 256 pp.

Evans, P. G. H. 1987. The Natural History of Whales and Dolphins. Christopher Helm Publication Ltd. London. U. K.

Kahn, B. 2003. Mamalia Laut Species Positively Identified to Date in Indonesia [online]. Apex Environmental. Available from http://www.apexenvironmental.com/ListIndonesia.htmI\#IDINDONESIA [6 January 2003].

Leatherwood, S. \& R. R. Reeves. 1990. Bottlenose Dolphin. Academic Press. Inc.

Leatherwood, J. S., \& G. P. Donovan 1991. Cetaceans and Cetacean Research in the Indian Ocean Sanctuary. Marine Mammal Technical Report 3. United Nations Environment Programme. Nairobi. Kenya.

Nowak, R. M. 1997. Spinner, Spotted, and Striped Dolphins. http://www.press.ihu.edu/books/walkers mammals of the world/cetacea/cetacea. delphinidae.stenella.html. Apri 1, 2004. 
Perlindungan Hutan dan Pelestarian Alam. 1984. Marine Conservation Data Altlas. Direktorat Jenderal Perlindungan Hutan dan Pelestarian Alam. Departemen Kehutanan. Jakarta. Indonesia.

Philips, J. D. 1998. Whales in Sulawesi, Indonesia. (jphilips@soest.hawaii,edu). Marine Mamals Research Program HIMB. University of Hawaii at Manoa. $30 \mathrm{pp}$.

Purnomo, F. S. 2001. Pola distribusi lumba-lumba Stenella. spp di perairan Pantai Lovina, Kabupaten Buleleng, Bali Utara. Skripsi. Program Studi IImu Kelautan. Jurusan IImu Teknologi Kelautan. Institut Pertanian Bogor. Bogor. 79 pp.

Porter, L. \& L. Chilver. 2002. Timor Sea Small Mamalia Laut Survey 2002: Information for Researchers. Hongkong. WWF Australia. Indonesia.

Rice, D. W. 1989. Sperm whale Physeter macrocephalus Linnaeus. 1758. In S. H. Ridgway \& R. Harrison (eds). Handbook of Marine Mamals. Vol. 4. River Dolphins and the Larges Toothed Whales. Academic Press. London/San Diego. 177233.

Rudolph, P., C. Smeenk, \& S. Leatherwood. 1997. Preliminary checklist of cetacea in the Indonesian
Archipelago and adjacent waters. Zoologische Verhandelingen. 312: 3-48.

Shane, H. 1990. Behavior and ecology of the Bottlenose Dolphin at Sanibel Island, Florida. In S. Leatherwood \& R. R. Reeves (Eds.). The Bottlenose dolphine. Academic Press. Inc. San Diego, C. A.

Silalahi, S. \& I. S. Suwelo. 2003. Binatang paus, lumba-lumba, dan pesut dengan keragaman jenisnya di Indonesia. Makalah Pertemuan Ilmiah Tahunan Ikatan Sarjana Oseanologi Indonesia. Jakarta. Tanggal 10-11 Desember 2003.

Weber, H. H. \& H. V. Thurman. 1991. Marine Biology. Harper Collins Publisher. Inc.

WWF-Hongkong. 2003. Marine mammals. In Marine mammals survey techniques. Proceedings of the Workshop on Cetacean Species Identification, Marine Mammals Survey Techniques and Review of Regional knowledge. Tanggal 29-30 Januari 2003. Departemen Kelautan dan Perikanan dan WWF-Indonesia. Jakarta. Indonesia. 